Article

\title{
Enhancing the Efficacy of Religious Peacebuilding Practice: An Exploratory Evidence-Based Framework for Assessing Dominant Risks in Religious Peacebuilding
}

\author{
Mark Owen * and Anna King * \\ Centre of Religion, Reconciliation and Peace, University of Winchester, Winchester SO22 4NR, UK \\ * Correspondence: mark.owen@winchester.ac.uk (M.O.); Anna.king@winchester.ac.uk (A.K.)
}

Received: 2 October 2019; Accepted: 7 November 2019; Published: 20 November 2019

\begin{abstract}
The 'risk assessment' in peacebuilding has become a standard, if sometimes slightly formulaic and performative, element of project design and written proposals. Largely driven by donor requirements and organisational procedures, the relatively new discipline and practice recognised as 'Religious Peacebuilding' has taken on many of the elements of 'secular' peacebuilding, including the risk assessment. This means that organisations increasingly have to attempt to understand the associated risks to projects with a religious dimension often without any specific guidelines, and in many cases, any relevant knowledge or previous experience of working with religious actors in peacebuilding. Consequently, the primary objective of this paper is to propose the first risk assessment framework for peacebuilding projects which explicitly focus on religious dimensions and actors. The framework is based on analysis of case studies and project evaluations from a number of contexts; and has the potential to make a tangible difference to the efficacy and impact of peacebuilding projects in a variety of post-conflict contexts. This paper will also briefly consider how the proposed framework relates to contemporary theoretical debates concerning the instrumentalization of religion, and increasing technocracy in peacebuilding theory and practice.
\end{abstract}

Keywords: religion; religious; peacebuilding; reconciliation; risk assessment; instrumentalization; technocracy

\section{Introduction}

The 'risk assessment' in peacebuilding projects has become a standard, if sometimes slightly formulaic and performative, element of project design and written proposals. ${ }^{1}$ If carried out by actors $^{2}$ with good contextual knowledge and conflict assessment and peacebuilding experience, it can undoubtedly be helpful in identifying potential challenges and barriers to a project's effectiveness early in the project planning phase; and should also be central to informing subsequent conflict sensitivity indicators. ${ }^{3}$ Seen as a potential problem by some, ${ }^{4}$ the relatively new theoretical and practical area

1 See for example: https://www.undp.org/content/undp/en/home/ourwork/democratic-governance-and-peacebuilding/ conflict-prevention-and-peacebuilding/conflict-analysis-and-risk-assessment.

2 In peacebuilding the term 'actors' is often used to refer to any party (individual, organisation, government, authority, etc.) involved in the conflict or peacebuilding processes. For a more definitive definition see: (Snodderly 2018).

3 See for example: (Conflict Sensitivity Consortium 2012; International Alert and Saferworld 2004).

4 See (Appleby et al. 2015). One of the themes addressed in this edited volume is whether or not much religious peacebuilding theory and practice is currently operating within existing (and restrictive) secular frameworks and discourses, and if so whether this to some extent undermines the true nature and attributes of religions' role in peacebuilding. 
recognised as 'Religious Peacebuilding' has taken on many of the elements of 'secular' peacebuilding, including the risk assessment. This is largely due to the fact that whilst donors are increasingly open to a religious dimension to peacebuilding projects, project expectations, formats and applications remain largely unchanged-with few exceptions. ${ }^{5}$ This means that organisations increasingly have to attempt to understand the associated risks to projects with a religious dimension often without any specific guidelines, and in some cases, any relevant knowledge or previous experience of working with religious actors in peacebuilding.

As a result, the primary objective of this paper is to propose the first risk assessment framework for peacebuilding which explicitly focuses on religious dimensions and actors. If theoretically and practically sound, a framework like this can make a tangible difference to the efficacy and impact of peacebuilding projects, and of enhancing the rebuilding of relationships across divisions in a variety of post-conflict contexts. It is therefore a potentially important advancement in religious peacebuilding. The framework proposed is based on close analysis of case studies and project evaluations from a number of contexts (see methodology section below). In a less structured way than presented here, it has been used to inform the design of several peacebuilding projects in Myanmar with positive results. ${ }^{6}$ Given the technical and analytical nature of risk assessments, in concluding there are two subsidiary areas with which this paper will briefly engage with. Firstly, some observations will be made in relation to previous concerns over the instrumentalization of religion in peacebuilding (Appleby 2000; Gopin 2000; Hertog 2010). Relatedly, brief consideration will also be given to whether a framework such as this contributes to a tendency towards technocracy (Mac Ginty 2012) in religious peacebuilding; and whether this is in any way detrimental to the development of theory and practice in the area.

\section{Methodology and Data Collection}

The data which inform the development of the proposed risk analysis framework have been collected by the authors over the last seven years whilst observing, researching and supporting peacebuilding and reconciliation projects with a religious dimension in a number of contexts including Uganda, Sri Lanka, Somalia, Syria/Turkey. However, the paper draws predominantly on data collected during several periods of fieldwork in Nepal from 2011-2015, and supporting three religious peacebuilding programmes in five different conflict areas of Myanmar from 2014-2019.

Data collection in Nepal was carried out by the authors during four periods of fieldwork (all between 3-6 weeks) in 2011, 2012, 2013, and 2015. The research focused on identifying and examining examples of religious involvement in post-conflict peacebuilding, and attempting to ascertain evidence of impact, and/or links to existing peacebuilding theory. Approximately 70 semi-structured interviews were carried out with religious and community leaders, and staff from faith-based NGOs undertaking peacebuilding initiatives. Workshops were also held in Biratnagar, Birgunj and Kathmandu with participants of community peacebuilding projects, with the primary aim of understanding how project beneficiaries viewed the involvement of religious actors and resources in peacebuilding initiatives. The authors were also partners in organising a national conference in Kathmandu in 2013, which brought together academics, practitioners and Nepalese government representatives to examine the possibilities and potentials of religious engagement in post-conflict peacebuilding in Nepal.

Data collection in Myanmar was orientated around of series of peacebuilding projects carried out by the international multireligious organisation Religions for Peace (RfP) ${ }^{7}$ in: Myitkyina, Kachin state;

5 For example, the authors have recently worked on a project supported by the GHR foundation (http://www.ghrfoundation.org) who are open to the possibilities that monitoring and evaluation of projects with religious dimensions might challenge existing conventions in measuring progress and impact in peacebuilding projects.

6 Two projects which were informed by the principles used in the risk assessment framework have been completed and evaluated, demonstrating a range of positive impacts from the projects. The evaluation reports are owned by Religions for Peace Myanmar/International, but may be available on request.

7 Religions for Peace is a Faith-based Organisation (FBO) which brings together religious and community leaders at international, national and local levels, and places a significant emphasis on the advantages a multireligious approach can 
Meiktila and Pyay in Central Myanmar; and Kyauk Pyu and Mrauk U in Rakhine state. The authors worked closely with Religions for Peace, carrying out an initial conflict assessment to help ensure project activities were as contextually specific as possible within funder's parameters. They were also commissioned to carry out project evaluations, and some training with project participants on conflict analysis and dialogue skills. Inevitably this meant that the researchers were both active participants in the project, whilst also observing and collecting research data; a methodological approach best described as Participatory Action Research. Data was collected through one to one semi-structured interviews and focus groups with over 200 project participants, and religious leaders and peacebuilding practitioners over five periods of research from 2014-2019. As part of the programme monitoring and evaluation procedures RfP project staff also collected quantitative data which was intended to demonstrate attitudinal and behavioural change in participants. This was also available to the authors, although was not influential in the development of this paper. The qualitative data collected in Nepal and Myanmar was analysed using a form of inductive context analysis in order to identify reoccurring and potentially important themes, which have directly informed the development of the proposed risk assessment framework.

The authors have expertise in Religious Studies, and in particular religious anthropology and ethnography. Consequently, the dynamic and multifaceted nature of the risks incorporated into the framework can be seen to be informed by an emphasis on the complex nature of lived religion, and the multiple identities of religious actors and leaders. Whilst acknowledging that religious peacebuilding case studies are always contextually conditioned (Shannahan and Payne 2016), this paper tests the hypothesis that, despite the inevitability of contextual specificity, it is possible to identify some common elements in religious peacebuilding which if properly understood and manged effectively can enhance peacebuilding in all contexts where engaging religious actors is considered beneficial. Therefore, the principal research questions which framed this study are: Is it possible to identify common factors and variables that shape the experiences and efficacy of religious peacebuilding in any given context? How does this relate to existing theoretical discussions on religious peacebuilding, and what if any are the implications for future debates in the subject area? ${ }^{8}$

Whilst as a concept and practice 'religious peacebuilding' has in recent years expanded exponentially, it remains neither well-defined nor universally accepted; illustrated by Coward and Smith's (2004) definition which presents religious peacebuilding as "the range of activities performed by religious actors and institutions for the purpose of resolving and transforming deadly conflict, with the goal of building social relations and political institutions characterized by an ethos of tolerance and nonviolence" (Coward and Smith 2004, p. 5). The term is used to refer to a wide range of different activities and initiatives. The following examples of 'religious peacebuilding' demonstrate this diversity: ostensibly 'secular' projects and activities carried out by Faith-based Organisations (FBOs); secular peacebuilding activities which engage with religious leaders and communities; projects which attempt to build bridges across religious communal divides; and the use of religious leaders, beliefs and scriptures to support peacebuilding goals.

Whilst some credence may be given to all these approaches, such a wide definition means that it is not always clear in studies what is being discussed; and importantly many of the activities under the broad banner of religious peacebuilding are not directly comparable. It is beyond the scope of this paper to examine this issue further. However, in order to facilitate comparative discussion, it is important is to clearly establish the type of peacebuilding work this paper is considering. The projects examined for this study focused predominantly on building/rebuilding relationships across religious and ethnic divides. The violent conflicts which led to these divides were driven by a myriad

bring to tackling a range of issues, including peacebuilding, addressing climate change, social and economic inequalities, supporting the Sustainable Development Goals, and nuclear disarmament. For more information, see: www.rfp.org.

8 This paper focuses on the first of these questions, whilst a related paper (which has been recently submitted by the authors for publication) deals more explicitly with the second research question. 
of complex reasons, including historical grievances, structural violence, and contemporary pressures, with religious identity playing an important role. The projects used two main approaches in an attempt to rebuild personal and communal relations: bringing participants from different religious and ethnic backgrounds together around common activities and causes which may or may not have a religious dimension; and more explicit interfaith/interreligious dialogues and activities. The projects were carried out by Faith-based Organisations, and whilst activities may not have always had an overtly religious theme or dimension, participants were engaged on the basis of their religious identity and/or membership of a religious community.

The authors spent several periods of time in each location observing the project activities, speaking and interviewing project participants and staff, carrying out staff and participant training, and undertaking evaluative processes on a number of projects. As a result, data used to inform this discussion are both qualitative and quantitative, collected during a series of one to one interviews, focus groups, workshops, informal discussions, workshop evaluation and feedback, as well as drawing on the projects' monitoring and evaluation data shared by the project staff. In common with many peacebuilding projects, whilst coordinated at a national level and in conceptualisation recognising broader regional and national issues and dynamics, the projects were implemented at community level and designed to be responsive to local issues and needs. Correspondingly the proposed framework deals predominantly with risks at a more localised level. That said, as will become evident, the risks identified here are often related to broader contextual dynamics and wider conflict complexes (Wallensteen 2012).

\section{Results}

\section{Eight Prominent Risk Factors in Religion and Peacebuilding}

Insights from the underpinning research have been collated and are presented here as 'eight prominent risk factors in religion and peacebuilding'. The eight factors have the potential to impact negatively on religious peacebuilding activities. Conversely, careful preparation, close monitoring, and preconceived strategies to mitigate the negative consequences of these factors have the potential to enhance the impact and efficacy of a peacebuilding project which has a religious dimension. The eight factors are not presented in order of priority, and are as follows:

1. Religions' relationship to political institutions, systems and movements;

2. The international dimension;

3. Religious leadership;

4. Organisational and staff identity;

5. Contextualisation of religious practices and beliefs;

6. The influence of religious literacy;

7. Socio-economic conditions of participants and staff;

8. The barometer of fear.

In order to facilitate the practical application of this theoretical framework the eight factors have been used to inform the development of a risk analysis table—see 'Religious Peacebuilding Risk Table' section below. If used systematically in the conceptualisation and design stages of a peacebuilding project, the table can be a useful tool for anticipating problems and developing strategies for mitigation. Ongoing monitoring of these factors as a project is implemented and developed, can help recognise increasing risks.

\section{Discussion}

Evidently the effectiveness of a method such as this is dependent on the theoretical robustness of the risk factors. As revealed, these factors have been identified during close observations and evaluations of a number of peacebuilding projects in a variety of contexts. A case study approach was 
used because it allows for the work of peacebuilding organisations to be examined in detail and in a real-world context (Denscombe 2014; Yin 2012); and this was seen as key to ensuring theoretical insights were also scrutinised for practical relevance and expediency. An approach often treated with some scepticism in the social sciences, case studies remain a valuable method for this kind of exploratory and inductive research, and for generating new and innovative hypotheses. "In general, case studies are the preferred strategy when 'how' or 'why' questions are being posed, when the investigator has little control over events, and when the focus is on a contemporary phenomenon within some real-life context" (Yin 1994, p. 1).

In order to further interrogate and corroborate the theoretical robustness of the factors proposed, the following section will cross-reference them with existing academic literature on peacebuilding, and religions' role in conflict and peacebuilding processes. Many of the challenges and issues detailed below are ones familiar to peacebuilding practitioners who have worked with religious communities and leaders, or those acquainted with the religious peacebuilding literature. However, the intrinsic value of this paper is not in revealing new or unknown challenges to religious peacebuilding projects, but in systematising this knowledge, and considering a methodical approach which enables the identification of a range of likely risks to peacebuilding project efficacy and impact, and possible ways to manage and mitigate these risks.

\subsection{Religions' Relationship to Political Institutions, Systems and Movements}

Contrary to claims of the inevitable and unrelenting march towards global secularisation (Bruce 2002), throughout the latter half of the 20th and early 21st centuries it has become increasingly recognised that religion's relevance to, and influence on, national and global politics has if anything increased (Snyder 2011; Schwarz and Lynch 2016). Toft et al.'s (2011) God's Century: Resurgent Religion and Global Politics is arguably the most ambitious and insightful study in this area to date. The study examines the proposed advantages and disadvantages of different relationships between religious and state institutions, and proposes that "religious communities are most likely to support democracy, peace and freedom for other faiths and least likely to take up the gun or form dictatorships, when governments allow them freedom to worship, practice and express their faith freely" (Toft et al. 2011, p. 18). Conversely, governments which "fail to respect the institutional independence of religious actors will encourage pathological forms of religious politics including religious based terrorism and religious related civil wars". 9

Toft et al.'s analysis of religion in relation to politics is nuanced and important; and crucially for this debate does a commendable job of firstly arguing that religion and religious actors will remain an influential force in political discourse and outcomes for the foreseeable future; and secondly that the dynamic and sometimes unpredictable relationship between religious and political actors can to some extent determine whether religion plays a positive or negative role in peacebuilding processes and initiatives. As they and others have aptly demonstrated, when religion and politics combine to fan the flames of exclusivist religious nationalism it can form a destructive mix which often results in extremely negative consequences; as has been evident in countries/contexts such as Afghanistan, the Balkans, India, Iran, Israel, Myanmar, Pakistan, Sri Lanka, and Sudan. ${ }^{10}$

There are a number of important considerations when attempting to understand and anticipate the possibilities of political relations impacting on more localised peacebuilding endeavours. Project participants whose religious traditions are state affiliated and/or have hierarchical structures through which polices and proclamations can be disseminated, may well be more swayed by political trends, power, and legislation. ${ }^{11}$ Strong national and/or local political support for a specific religious tradition

9 https://www.thinkingfaith.org/articles/book_20110701_1.htm.

10 See for example: McTernan (2003); Juergensmeyer (2003); Fox (2004); Al-Rasheed and Shterin (2009); Herbert (2009); Stern (2009); Eller (2010); Juergensmeyer and Kitts (2011).

11 Countries such as India, Iran, Myanmar, Saudi Arabia and Sri Lanka aptly illustrate this phenomenon. 
can also create barriers to building trust and relations between religions at community level; and from a dominant religious group's perspective, sometimes undermine the belief that there is any necessity for peacebuilding and reconciliation efforts at all. ${ }^{12}$ Less hierarchical religious traditions and/or minority groups can also actively court political allegiances and affiliations; particularly if aligning themselves with political actors and institutions may offer an element of protection or favour. Historical examples of this include the Alawis in Syria, Sunni Arabs in Iraq, or the Tibetan Government in Exile's attempts to court global political support for their campaign for an autonomous state (Kolas 1996). The probability that political factors could be influential is also increased when division and tensions are related to religious/ethnic identities and boundaries; making a religious community potentially more open to political affiliation and support.

In his 2012 study on Canadian FBOs, Parras argues that the often presumed separation between religion and politics has always been a largely "secular fiction"; and in many countries it has never existed to the extent often portrayed. Certainly it is the case that at more localised levels the lines between ethnic, religious and political identities are often blurred, which can mean that the politicisation of religion, and political influence on religious actors, is more likely. Whilst structures, communications, and contextual conditions, go some way to determining the influence of political dynamics on local contexts, modern day communications networks mean that national or regional level political changes can be felt swiftly at local levels. This is perhaps particularly true in conflict contexts where competing interests and insecurities can mean communal relations are particularly volatile and open to influence.

Whilst it is difficult to predict the impact of political change on an already volatile environment, what can be said with some certainty is that support and participation for peacebuilding projects can change exceptionally quickly depending on perceived or real political threats, challenges, incentives and personnel. Preparation for mitigation requires a comprehensive mapping process during project development; working closely with local stakeholders in order to fully understand existing political dynamics, and their relationship to religious individuals and communities who are to be engaged in the project. From this it is often possible to identify, and at least partially anticipate, likely changes and threats to project support and participation. Building relations with local political actors is also a highly desirable enterprise. Even political actors who appear hostile and publicly opposed to reconciliation and peacebuilding values and objectives, can on a personal level be unexpectedly open to dialogue, if not agreement. Jonathan Powell, who was central to the Northern Ireland peace process, has personally demonstrated the importance of building relationships with presumed adversaries as part of successful peacebuilding processes (Powell 2015).

\subsection{The International Dimension}

Closely related to the national political dimension, the role of international 'third party actors' and 'the international community' in conflict and peace processes has become increasingly important and influential in the contemporary world (Bhattarai 2016; Lundqvist and Öjendal 2018). Ostensibly driven by commitments to human rights and laws, in reality international responses can also be closely linked to countries' foreign and domestic political dynamics and agendas. We can see the results of these complex processes in the apparent inconsistency illustrated in international responses to the violence against Muslims in Rakhine ${ }^{13}$ or the Sri Lankan government's defeat of the LTTE, ${ }^{14}$ when compared to reactions (or lack of) to Saudi Arabia's involvement in the Yemen conflict and crisis, ${ }^{15}$ or

12 On several occasions in workshop in Rakhine in 2017 and 2018 participants clearly expressed the view that as Buddhists were the majority religious group and supported by the Burmese military (Tatmadaw), there was no need or desire as the dominant group to reconcile with Muslims.

13 https://en.wikipedia.org/wiki/International_reactions_to_the_2016\%E2\%80\%9317_Rohingya_persecution_in_Myanmar.

14 http://www.ohchr.org/EN/HRBodies/HRC/RegularSessions/Session30/Documents/A_HRC_30_CRP_2.docx.

15 https://en.wikipedia.org/wiki/International_reactions_to_the_Saudi-led_intervention_in_Yemen_(2015\%E2\%80\% 93present). 
the role of western governments in Iraq, Libya, or Syria. New media platforms in particular mean that information about international declarations, aid assistance, and reports can be disseminated extremely quickly, which can impact on even very rural and local contexts surprisingly swiftly. When perceived negatively this can be highly detrimental to a conflict and/or peacebuilding context: a pertinent example being the increasing anger and hostility of Buddhists in Rakhine towards the international community and international development workers and organisations. ${ }^{16}$

The increasingly transnational nature of many religions also requires consideration (Rudolph 2018). With networks, affiliates and influencers spread across the world, the global nature of religious communities can have significant implications for peacebuilding at local level. From a positive perspective, even relatively remote communities and projects can feel connected to, and supported by, global networks. Perceived international support can make a significant difference to the status of project, willingness to engage by local people, and prevailing attitudes towards peace and reconciliation. ${ }^{17}$ The work of the international organisation Religions for Peace is an excellent example of the positive impact this phenomenon can have. ${ }^{18}$

Conversely, as ISIS starkly demonstrated in their successful mobilisation and recruitment of foreign fighters in Syria and Iraq ${ }^{19}$ sophisticated international communication and media strategies can have hugely detrimental consequences which are very difficult to counter even with significant technological resources and peacebuilding expertise and support (Aly et al. 2017; Shehabat and Mitew 2018; Abdelrahim 2019). In addition, the increasingly global nature of religious organisations and networks can tend towards a homogenised view of religious identity and communities, and collapse of religious/ethnic contextual specificity. This can, and has, helped perpetuate religious stereotypes and resulted in local incidents or conflicts transcending contexts and becoming globalised disputes. A pertinent example is the worldwide rise in Islamophobia (Morgan and Poynting 2016).

Given the speed and proliferation of new media, the global international dynamics can be hugely influential on even small-scale localised peacebuilding efforts. Whilst often little can be done at local level to control the deliberations and actions of international and transnational communities and organisations, work can be done on the ground in an attempt to predict international scenarios, and future proof against negative impact. Consideration of the local context and religious groupings in relation to national and international networks and dimensions is necessary—and this need not be onerous but a relatively simple process of mapping key relationships and issues. Some steps can also be taken to mitigate the potentially negative impact of international developments in project design and initiation. Establishing clear communication within and between project participants and participating communities is extremely important. Key actors and stakeholders, including religious leaders, should be ready and willing to speak out to emphasise the importance of peacebuilding and diffuse tensions as they arise: and there are abundant examples of this proving an effective strategy in practice. ${ }^{20}$ The international dimension is one factor that requires close and continual monitoring in order to limit its negative impact on a local peacebuilding project.

16 https://www.reuters.com/article/us-myanmar-rohingya-un/u-n-warns-aid-workers-of-rising-buddhist-hostility-inwestern-myanmar-idUSKBN1AQ16P.

17 In interviews carried out by the authors in Myanmar and Nepal from 2011-2019, participants repeatedly revealed that they took part in projects because the projects were connected to an international organisation. Motivations ranged from feeling supported and giving the project legitimacy, to more instrumental reasons such as greater access to funding or international networks/travel/opportunities.

18 www.rfp.org.

19 https://www.bbc.co.uk/news/world-middle-east-41734069.

20 https://beyondborders.net/teaming-up-with-religious-leaders-to-prevent-violence-against-women/; https:/www.sfcg.org/ when-it-comes-to-conflict-religion-is-part-of-the-solution/. 


\subsection{Religious Leadership}

The importance of religious leadership has been widely noted and examined in relation to religious peacebuilding, ${ }^{21}$ with studies such as Timothy Sisk's (2011) edited volume adeptly demonstrating the complex nature of religious leadership in both driving violence and building peace. Despite increasingly complex theoretical conceptualisations, the principal assumption in the practice of peacebuilding remains that if religious leaders support a peace project it will likely be more effective, and if not then their influence will be at best neutral, and at worst detrimental. This is a seemingly logical and sometimes accurate starting point: but overly simplistic for a more accurate assessment of risk to localised peacebuilding initiatives.

In practice the involvement and influence of religious leadership on local peacebuilding initiatives can often be variable depending on a range of complex factors. As Lederach (1997) first noted, for a variety of reasons not all religious leaders are well placed to be effective peacebuilders. ${ }^{22}$ Religious leaders who are involved in, or sympathetic to, peacebuilding projects (and particularly inter/multifaith initiatives) often have relatively liberal religious ideologies and attitudes. However, this stance may not necessarily represent attitudes and understandings within their wider religious communities. Whilst religious leaders should by their nature 'lead', their role is often also to represent their community (Sampson 1997); and if divisions and tensions exist within a community regardless of personal views leaders may come under pressure not to support peacebuilding efforts. ${ }^{23}$ Going against prevailing opinion may undermine a leader's integrity and authority (and ability to promulgate peace) in a community, and/or put them in personal danger: and this possibility needs to be considered when asking religious leaders to participate in a project. The converse can also be true: and if a religious leader is pressurised into participating in peacebuilding by communal consensus, or does so to boost their reputation and influence, then this can be detrimental to the credibility and effectiveness of a project.

Relations between religious leaders from different religious traditions, or different branches of (seemingly) the same religious tradition, ${ }^{24}$ can also be highly complex. Disparities in participation amongst religious leaders can be representative of communal opinions and attitudes towards project; indicative of personal relationships; or an intentional attempt to incite apathy or antipathy towards an initiative. This can be particularly problematic when etiquette or tradition prevents religious leaders from publicly questioning the speech and actions of their peers. This scenario was evident in Myanmar, when Buddhist religious leaders were initially reticent to speak out against the militant monk U Wirathu who publicly incited violence against religious minorities (Walton and Hayward 2014). Furthermore, in some contexts engagement with religious leaders from certain religious traditions or communities may preclude engagement with others; e.g., if Ahmadiyya leaders are involved in a peacebuilding initiative this may lead to a lack of engagement or withdrawal by Muslim leaders.

This brief discussion on the complex nature of religious leadership is not intended to be exhaustive, but is indicative of the level of comprehension required when considering the potential of religious leaders in a peacebuilding initiative. Whilst a popular and sometimes exceptionally effective peacebuilding method, engagement of religious leaders in peacebuilding is rarely straightforward. The presumption in project conceptualisation that even prominent religious leaders can bring about a profound change in those who have been affected by violence, oppression and fear can be greatly misplaced. As Sisk notes in summarising the findings of a range of studies on religious leadership in

21 Lederach (1997); Sampson (1997); Appleby (2000); Gopin (2000); Hertog (2010); Sisk (2011); Frazer and Owen (2018); amongst others.

22 See also Fitzduff in (Sisk 2011).

23 See Fitzduff in (Sisk 2011) for examples from Northern Ireland 2011; p. 155.

24 There are examples in most religious traditions where from an 'outsider's' perspective it may seem that religious leaders share a religious identity and tradition, whereas in fact the religious leaders themselves might see another branch or school as an inauthentic and illegitimate expression of their own religion. 
conflict and peacemaking; "these case studies provide evidence that religious leaders have very little opportunity to promote peace when the social, economic and political conditions are prohibitive" (Sisk 2011, p. 235).

During project planning a systematic approach to mapping and profiling religious hierarchies and leaders is essential. Understanding the potential influence of religious leadership on a peacebuilding project, and mitigating risk, requires knowledge of the relevant religious traditions' hierarchies and structures, and the participating leaders' standing and influence in a community. It is also vital "to have a clear understanding of the wide range of types of religious leaders and the ways they interact with social conflict dynamics" (Sisk 2011, p. 232). Engaging experts on pertinent religions may well be necessary, and local contextual knowledge is crucial as relationships between religious leaders and traditions can be complex and personal. It is also important to at least be open to the possibility that if motivations for participation are questionable, or in situations where their participation may emphasise divisions and tensions, it may be preferable not to engage with religious leaders.

\subsection{Organisational and Staff Identity}

Organisational structure, skills, competency and capacity all have a role to play in effectively delivering a peacebuilding project, and to some extent determining its impact. However, the 'characteristics' of an organisation, and staff identity are areas which in religious peacebuilding require specific consideration and understanding in assessing and managing risk.

There have been a number of studies which have examined the religious identity of an organisation in peacebuilding and humanitarian work: ${ }^{25}$ identifying a range of advantages and disadvantages to being a Faith-based Organisation (FBO). Being a FBO might give access to private funding (Boesenecker and Vinjamuri 2011); afford long-term engagement with communities; secure greater access and trust; attract support from senior religious leaders; as well as provide credibility and authority in some contexts. Conversely it might create suspicion about professionalism or intentions; prevent engagement from some project participants and donors/partners; and place expectations and restrictions on project parameters and activities. A similar range of problems can occur for secular peacebuilding organisations attempting to engage with religious actors.

Evidently there is little that can be done by project staff about an organisation's identity, mission and foundations. Whilst transparency is always important, some careful consideration should be given to the extent to which organisational perceptions might impact on a project's reputation and effectiveness, and how this can be handled in a skilful and sensitive way. For example, in an attempt to counter perceptions that the main purpose of its work was evangelism, World Vision International in Nepal ensured its staff profile and recruitment reflected the religious and ethnic diversity of the places in which it worked. ${ }^{26}$

Even more complex and potentially influential than organisational identity is the identity (real and perceived) of project staff. In many academic disciplines the 'insider/outsider' dilemma is one that has been thoroughly scrutinised (Dwyer and Buckle 2009), and is a topic also highly relevant to religious peacebuilders. Staff insider or outsider status has been recognised as bringing a range of possible benefits and challenges in religious peacebuilding (Mubashir and Vimalarajah 2016). There are numerous complex ways in which staff identity can affect a project. For example: staff with no relationship or religious/ethnic affinity with conflicting parties may be seen positively, as a neutral third-party mediator (Bercovitch and Kadayifci-Orellana 2009; Frazer and Friedli 2015). Conversely their lack of shared identities may see them perceived as untrusted interlopers. Staff from a religious majority may find it difficult to gain trust with minority groups, especially if minorities have suffered oppression or violence at the hands of members of a religious majority. Staff from a religious minority

25 See for example Schwarz (2018); Appleby et al. (2015); Clarke (2008); Haynes (2007).

26 Interview: World Vision International staff member, Kathmandu, Nepal 12 June 2013. 
background may not be afforded due respect, or be able to win trust from all participants. They may also feel it is in their interest to be subservient to majority group members, thereby compromising the integrity of the project, and its activities and objectives. ${ }^{27}$

Staff recruited locally to work on peacebuilding projects may also have multiple identities within a community; such as religious or community leaders, or business or political interests. This eventuality is more likely when a local implementing partner or organisation originally began as an interreligious group (a common origin of many community FBOS) but has subsequently become an operational peacebuilding organisation. Multiple identities can have advantages; as staff may be able to command respect within a range of different social groupings. However, there can also be confusion over the status of the individual at different times, which can impede participation and the ability for project participants to feedback honestly and critically.

Evidently selection of key staff in a project will have a significant impact on the effectiveness of a project. Steps can be taken to prevent negative impact; and ideally members of staff should emphasise their principal identity as a peacebuilding professional. If staff are local, or share identities with project participants, then an ideal might be representation amongst staff from all religious/ethnic groups involved in the project. However, dependent on resources and skills this may not be a feasible option, in which case it may well be better to bring someone in from outside the immediate context so that their religious/ethnic identity is not so relevant. This can help in them being associated primarily with their professional role. It is often not possible to avoid all issues related to staff identity. However, transparent discussion between participants and staff, and between staff members, can help identify and acknowledge problems and prevent them from becoming a significant negative factor.

\subsection{Contextualising Religious Practices and Beliefs}

Within peacebuilding studies and practice increasing attention has been paid to elicitive and more local forms of peacebuilding (Leonardsson and Rudd 2015). The emphasis on local resources and context in religious peacebuilding often manifests in two ways. Firstly, if an assessment or knowledge of local contexts appears to indicate that religion is important to local people, then it is assumed that religious actors must be engaged peacebuilding. Secondly, peacebuilders find out the religious identities of communities/project participants, and incorporate popular ideas about how religious beliefs and practices support peace into project aims and activities. We can see this clearly apparent in the relatively generic formats adopted in most religious peacebuilding projects activities: engage with religious leaders in an attempt to get them to support a project; form an intra/interfaith groups with the aim of learning about each other's religions; draw on religious scripture and teachings to find aspects which seem to support the building of peaceful and harmonious communities.

Whilst some of these activities and ideas may have a positive impact, this generic approach does not take into account the complex and dynamic nature of lived religion; which often means that highly specific religious ideas, beliefs, practices, traditions, prayers, icons and spiritual leaders are influential and important in different contexts. As Marc Gopin emphasises, "[I]n the real situation of conflict, priority must be given to an inductive approach, which involves an empirical investigation of a conflict scenario: listening to the needs being expressed in the conflict and then exploring a series of religious ideas, values, and institutions that may be appropriate for that conflict setting". ${ }^{28}$ Similarly Hertog argues that in order to "develop insight into the added value of specific religious actors in specific conflict situations ... in-depth knowledge of both the conflict situation and the involved

\footnotetext{
27 This eventuality was identified from a project evaluation in Myanmar, where a Muslim worker admitted that they felt unable to ask Buddhist participants to undertake certain activities, and it was in their best interests (and that of their community) not to risk upsetting or offending Buddhist participants in anyway, and to accept that some proposed project activities could not take place (or indeed be creative about the extent to which they had).

28 Gopin (2000, p. 26)
} 
religious traditions and organizations is required in order to devise the best ways in which religion can contribute to a peacebuilding process" ${ }^{29}$

Generic religious peacebuilding activities often assume a level of liberalisation and socio-religious norms which are not always present, and this approach to religious contextualisation is likely to at best limit the effectiveness of the project, and at worst prove detrimental. Activities which assume the open nature of communities, such as group scriptural exegesis, unconditional participation of women, or visiting each other's places of worship, can seriously undermine a project's legitimacy and participation levels - resulting in 'preaching to the converted' whilst failing to engage more conservative religious actors that peacebuilding projects need to reach.

It seems apparent that one of the reasons for the lack of more creative and contextually sophisticated approaches to religious peacebuilding is the relative lack of expertise and resources in this area. This is being addressed by increasing training and education on religion and peacebuilding; and the United States Institute of Peace's new handbook on Religion, Conflict and Peacebuilding is a pertinent example (Frazer and Owen 2018). As with many of these risk factors, informed consultation, and a close and respected relationship with local religious leaders and peacebuilders can lead to a better understanding of how religion is most likely to support peacebuilding in the specific context.

\subsection{The Influence of Religious Literacy}

Related to religious contextualisation, the impact of 'religious literacy' on religious peacebuilding projects is one that is often ignored in project proposal and design; and this can have a significant impact on the anticipated outcomes of a project. This oversight is perhaps inevitable due to a fundamental tension involved in estimating and/or anticipating the religious literacy of project participants. In order for a project to be seen to qualify as 'religious peacebuilding' the presence and added benefits of the religious dimension needs to be clarified and emphasised. The usual way of doing this (particularly for organisations/individuals not necessarily proficient or confident in working with religious actors) is to (over)emphasise the way in which religious teachings and scripture are understood, accepted and influence members of a community.

However even in 'deeply religious' communities and societies, knowledge of religious scriptures and teachings can be surprisingly low. Indeed, an emphasis on these aspects of religion has been attributed to a colonial 'protestantization' of religion, ${ }^{30}$ and not an accurate reflection of how religion is understood and practiced in many cultures throughout the world (Almond 1988). It may well be that other dimensions and functions of religion are more important and influential in a society than knowledge of religious teachings and scripture. Frazer and Owen (2018) in their work on analysing the potential of religion in peacebuilding processes articulate five dimensions of religion which need to be given equal consideration when devising a peacebuilding project. These are: Religion as a set of ideas; Religion as community; Religion as an institution; Religion as a set of symbols and practices; and Religion as spirituality (Frazer and Owen 2018).

A narrow focus on certain types of religious knowledge and literacy, and failure to carry out a broader analysis of religion's potential in peacebuilding, can result in a project which struggles to achieve the type of positive results hoped for. This is a risk factor that may not change significantly throughout the course of a project. However, the complexity and agency of different religious dimensions will require deep analysis during the planning phase of a project: and as mentioned above, increasingly resources are being developed for this purpose (Frazer and Owen 2018). Project designers must also be cognisant of the fact that the way in which religion is influential within communities may

29 Hertog (2010, p. 116).

30 A term used to describe a process whereby non-Christian religions were interpreted through the lens of the western Christian tradition. For a detailed description and critique see Almond (1988). 
not only vary from religion to religion, but also within religious traditions if allegiances to different schools or leaders are divided.

\subsection{Socio-Economic Conditions of Participants and Staff}

Arguably the most influential factor on participation in local peacebuilding projects is the socio-economic conditions of project participants and staff. Participation in project activities, however minimal, requires people to give up time not only for the activities but in many cases for travel to and from a project location. For people who live in communities with low socio-economic development and opportunities, this can be a significant barrier to involvement. Consequently, projects can unintentionally privilege more materially wealthy, and often educated middle-class members of a community. This runs contrary to evidence which suggests that members of lower socio-economic groups, or those that live in contexts where significant inequalities exist (Fjelde and Østby 2014), are mostly likely to be affected by communal violence.

Attempts to address this challenge in development and peacebuilding projects can include providing food, and/or 'transport' or per diem payments for participation; and this is certainly a popular strategy which is tried and tested. ${ }^{31}$ However, this can (and does) also mean that participants attend projects to gain the benefit of the incentives, and whilst motivation for participation might not necessarily run contrary to positive impact, it would perhaps be better if participants were convinced of the worth of religious peacebuilding projects by other means. One way to do this might be to include a more sustainable and integrated economic dimension, such as cross-religious/ethnic social enterprises or cooperatives. This is a method that has worked to good effect in some contexts (Business for Peace 2014), and may be worth considering; although evidently it requires expertise and resources in order to implement and mitigate risk.

These considerations can also extend to local staff, particularly where positions are part-time or relatively short-term contracts, and in contexts where wages for local staff can be very low. In this situation staff may need to supplement income with additional employment and activities, and this can impact on commitment to the project. It may also complicate their role in the project with participants. Resentment towards staff at national or international level that are more generously salaried can also create tensions and discord within a project or organisation. Volatility in socio-economic conditions can also have a major impact, and can be driven by factors such as resource scarcity due to security concerns and disrupted supply chains; environmental impact on food production and labour; in investor confidence; economic conditions of associated markets; as well as broader political dynamics, divestment, boycotting, and targeted sanctions. All of these factors must be considered in planning if economic factors are not to dictate project participation.

\subsection{The Barometer of Fear}

As a final 'catch all' risk factor, monitoring fear and insecurity in a community can be an effective, if non-specific indicator of the likely continued success and impact of a peacebuilding project. Fears and insecurities directly related to project participation can be driven by wide-ranging factors, many of which are outlined above. However, in situations where participants are not entirely sure themselves of the more complex causes and drivers, or where participants are unable or unwilling to articulate their reasons for non-participation or withdrawal, monitoring fear can allow people to express themselves in a simple but powerful way that does not demand deeper understanding or articulation.

Feelings of fear and insecurity are important indicators that should be monitored continuously throughout the course of a project. Key actors and stakeholders, and in many communities these can

31 This is a strategy widely used by INGOs and civil society organisations. For example during research in Adjumani, northern Uganda, several project coordinators revealed that paying 'chair money' was the only way to get community participation in peacebuilding training workshops: Adjumani, Anonymous Interview: 2019. 
be religious leaders, who are embedded and respected in communities are amongst the best placed to gauge feelings of anxiety and insecurity. That said, it is important to recgonise that monitoring and measuring fear and insecurity is not straightforward. Evidently it is highly subjective, likely in situations of conflict to be extremely volatile, and encompasses many complex elements, which makes attribution extremely difficult. This is certainly a factor which can benefit from greater exploration and research, and cross-disciplinary insights and collaboration.

\subsection{Religious Peacebuilding Risk Table}

Taking account of the eight risk factors identified, the example table below is intended to be indicative of how these insights could be applied; and not prescriptive or exhaustive. Suggested activities in the course of project preparation are intended to offer broad guidance on the type of issues which need to be considered, but evidently contexts, access, resources and expertise will to some extent dictate what is viable and achievable. Similarly, indicators and methods of monitoring need to be more specifically developed in relation to the project, contextual issues and challenges, and available resources. Many of the activities and areas which require monitoring are overlapping, and if responsibilities are clear, an exercise such as this should not be onerous. Once completed the framework can conceivably be a useful and effective way of managing and mitigating risk, and subsequently enhance the efficacy of religious peacebuilding projects. A blank copy of the table is available for use in project planning. ${ }^{32}$

\subsection{Risk Analysis and Contemporary Religious Peacebuilding Theory and Practice}

A short process of situating this article within current debates in religious peacebuilding provides an opportunity to make some modest observations and contributions to the area. As well documented, for much of its relatively short history religious peacebuilding has been dominated by Appleby's (2000) 'ambivalence thesis'. However more recently (led largely by Omer $(2012,2018)$; Appleby et al. (2015)) theoretical ideas in religious peacebuilding have become increasingly nuanced and sophisticated. The recent Oxford Handbook of Religion, Conflict, and Peacebuilding (Appleby et al. 2015) is the best example, claiming to provide "a comprehensive, interdisciplinary account of the scholarship on religion, conflict, and peacebuilding. Extending that inquiry beyond its traditional parameters, the volume explores the legacies of colonialism, missionary activism secularism, orientalism, and liberalism". ${ }^{33}$ A series of essays from a range of disciplinary perspectives, a central question explored is whether a form of peacebuilding rooted in religious traditions and ethics results in a more holistic and transformative 'justpeace', as opposed to existing liberal peace models which are rooted in western values and colonialist narratives, and therefore often complicit (whether intentional or not) in sustaining structural injustice and violence. By its nature it also tends to ignore or subvert local indigenous knowledges and traditions of peace and reconciliation.

32 https://winchester.ac.uk/media/content-assets/documents/rke-documents/Religion-and-Conflict-Analysis-Template-RiskAssessment-table-Nov-2019.pdf.

33 See preview https://oxfordindex.oup.com/view/10.1093/oxfordhb/9780199731640.001.0001. 
Risk Factor Project Preparation Activities
Mapping of and existing and potential relations between political actors and religious institutions and communities. movements

Mapping of current internal perspectives on, and relation with, the country/s where the projects are taking place, an

Formulating a comprehensive understanding of religious leadership and hierarchies, and relationships within and between religious traditions.

Careful consideration of how organisational characteristic may impact on project effectiveness, and how it should be

4. Organisational and staff identity communicated to project participants.

Careful consideration of staff identity and recruitment.

Openly acknowledging and sensitively discussing the potential for staff identity to impact on a project.

5. Contextualisation of religious Analysis of religious resources for peacebuilding within the practices and beliefs Analysis of religic
given context.

Analysis and understanding of the levels of religious literacy

6. The influence of religious literacy Analysis and understanding of the the specific conflict being addressed.

Level of Risk 1-5

Indicator/s

\section{Methods of Monitoring}

1. Project participants' political rhetoric and perceptions of change.

Level of political resistance/support for peacebuilding at a local/regional level.

3. National political rhetoric concerning religious affiliations, groups and actors.

Local attitudes towards international actors an their positions on the conflict.

Government/national statements and declaration on relations with the international community.

3. Changes in international involvement or interest in the context/conflict.

1. Language used by religious leaders and communities to talk about other leader/religions. Level of pesticipation peacebuilding projects and activities.

1. Perception of organisation amongst communities

2. Peer and participant feedback on staff identity and capability. and project participants.

1. Ongoing dialoge with project patie trusted religious/community actors and leaders.

2. Dialogue with local political institutions and actors.

3. Observing relevant social media groups and discussions.

4. Analysis of political statements and policies on religion/religion's role in conflict and peacebuilding.

1. Ongoing dialogue with project participants, and trusted religious/community actors and leaders.

. Observing traditional and social media coverage of international involvement in conflict.

International declarations, reports, investigations concerning conflict context.

1. Ongoing dialogue with project participants, and trusted religious/co Public statements or declarations.

3. Public religious teachings and sermons.

1. Ongoing dialogue with project participants, and Recod religious/community actors and leaders. 2. Recording levels of attendance and participation in activities, and reasons given for non-participation.

1. Contribution and effectiveness of religious resources in achieving broader peacebuilding objectives

1. Ongoing dialogue with project participants, and Levels of engagement with religious dimensions of $\begin{array}{ll}2 . & \begin{array}{l}\text { Recording le } \\ \text { in activities }\end{array}\end{array}$ trusted religious/community actors and leaders. peacebuilding project. in activities.

1. Contribution and effectiveness of religious resources in achieving broader peacebuilding objectives (measured by project M\&E framework). Ongoing dialogue with project participants, and
trusted religious/community actors and leaders. Levels of engagement with religious dimensions of
Recording levels of attendance and participation in activities. 
Risk Factor Project Preparation Activities
Careful consideration of the socio-economic conditions of target participants, and methods for supporting participation.

7. Socio-economic conditions

participants and staff.
Level of Risk 1-5

$$
\text { Indicator/s }
$$

Numbers of participants and motivation Nor participation.

for participation.
2. Changes in economic conditions in local

context/community.

3. Broader regional/national economic condition and trends.

1. Project participation.

As part of baseline data collection, establish levels of fear and

2. Levels of anxiety amo
1. Peer and group feedback on participation.

Ongoing dialogue with project participants, and trusted religious/community actors and leaders.

Observing traditional and social media coverage of economic conditions and dynamics.

Peer and group feedback on participation.

2. Ongoing dialogue with project participants, and trusted religious/community actors and leaders. 
Perhaps inevitably (and reassuringly) authors' opinion on the legitimacy and effectiveness of liberal peace, and its relationship to the neologism of 'justpeace', are varied. Pertinently the volume is also concerned with the implications of this debate for examining and enhancing peacebuilding practice. Marc Gopin reflecting on his own experiences of conflict resolution practice over 30 years suggests that binary polarisations of religious and secular approaches to peacebuilding are based on false dichotomies which do not reflect the demand for creativity and synthesis in peacebuilding in real life situations of conflict. He argues that it is the integration of all approaches to peacebuilding that offer the best hopes for achieving just and sustainable peace (2015).

The evidence and experience which informs the development of this framework would concur with this proposition. Whilst complex theoretical rejections or reorientations of liberal peacebuilding are appealing, and arguably necessary for theoretical development of the area, often in real life situations of violent conflict relations between the religious and secular are complex, often incongruous, but also vital for peacebuilding organisations and initiatives to be effective. Whilst a risk analysis framework such as this might be seen to instrumentalise religion (a concern consistently identified in religious peacebuilding literature (Appleby 2000; Gopin 2000; Hertog 2010)), and/or contribute to an increasingly technocratic and bureaucratic approaches to peacebuilding practice (Mac Ginty 2012, p. 288), such interpretations would be to misunderstand the purpose of such an endeavour, and the diverse nature of religious actors' motivations and identities.

As Omer (2018) has recognised, binary notions of the instrumentalization of religion fails to acknowledge the internal diversity within religious traditions and actors, and their multiple needs and roles. The recent Religions for Peace 10th World Assembly in Lindau, Germany clearly demonstrates that many religious actors can competently negotiate both religious and secular realms and priorities in recognising the shared concerns of all humanity concerning the climate crisis, the need for inclusive sustainable development, and in the pursuit of positive peace. ${ }^{34}$ This is also evident in local communities affected by violence, where desires for socio-economic development, functioning institutions and governance, law and order, human rights, and gender equality, combine in complex ways with religious ethics, beliefs and practices. The proposed framework recognises 'the complex reality of religious peacebuilding' (Hertog 2010), and the importance of contextual specificity, and attempts to establish a creative space where religion is seen as legitimate, vital and comprehensible resource in a domain still largely dominated by 'secular' discourse, actors, frameworks and funders.

\section{Conclusions}

The eight risk factors presented here are drawn from several specific conflict contexts, and whilst not claiming to be exhaustive, are an attempt to balance theoretical and contextual specificity with universally applicable peacebuilding considerations. To our knowledge this is the first concerted attempt to bring a range of risk factors associated with religious peacebuilding, into systematic, analytical framework, with a practical and applicable use. It is an attempt to go beyond simplistic understandings of religion in peacebuilding, which can often present it as isolated from contending factors in peacebuilding processes, and re-embed religious peacebuilding within the conflict context. It recognises that religion's potency as a peacebuilding tool is sometimes as dependent on complex political, social, and economic forces, as it is on religious authority, structures, and leaders. Whilst the framework is predicated on quantitative and qualitative data from a number of projects, and tested to a modest extent in Myanmar with some promising results, it is clearly an exploratory attempt at such an endeavour and requires more rigorous testing and critique. Undoubtedly it can be improved, and the framework presented here is intended as a point of departure for further work in this area.

The eight factors proposed range from the personal circumstances of staff and project participants, to national interests, international relations and the politics of external countries. This offers an

34 https://rfp.org/home-3/10th-world-assembly/. 
indication of the complex influences and dynamics which inform many peacebuilding contexts, and evidently each factor requires greater research and understanding. Additional research as to whether these factors are universally applicable in other contexts is critical; as is consideration as to what other dimensions need to be given close consideration when planning and implementing religious peacebuilding projects. Devising new risk factors will also necessitate consideration of ways in which theoretical insights can be turned into practical tools and can stimulate innovation and further developments in this area. This paper has drawn on data from 'formal' peacebuilding projects, planned and initiated by national and international organisations and actors. Important alternative avenues for research and data collection include less formal mechanisms and methods of peacebuilding carried out by local, indigenous religious and cultural actors. Future research could also benefit greatly from an increased cross-disciplinary approach, with studies integrating methods and insights from social psychology and the sociology of religion, conceivably offering greater insight.

The factors presented here are useful for initially assessing existing risks, but equally their strength lies in helping continually monitor potentially negative context dynamics, and in devising and preparing mitigation strategies. Tasks and activities associated with building resilience to changing dynamics should be done in an open, intentional and pre-emptive way, involving project participants and if possible wider community members: and not be a reactive response to negative changes. For many of the risk factors, local contextual knowledge is imperative, but some expertise and experience in understanding the complex realties of lived religion is also vital. Evidently peacebuilding project staff cannot be expected, and are unlikely to be, experts in religion. As a result building key collaborations with experts and partners is crucial - and the inclusion of this kind of expertise and partnership building should be an integral part of conflict and context assessments, and project designs and funding applications. Funders must also take responsibility for ensuring this happens and resources are available.

Author Contributions: Both authors contributed substantially to the work, including participating in fieldwork trips where data was collected, and in the analysis of the data and writing of the article. Conceptualization, M.O.; Methodology, M.O. and A.K.; Formal Analysis, M.O. and A.K.; Investigation, M.O. and A.K.; Data Curation, M.O. and A.K.; Writing-Original Draft Preparation, M.O.; Writing-Review and Editing, M.O. and A.K. Authors have reviewed and approved the submitted version of the article, and agree to be personally accountable for their contributions, and ensuring the accuracy and integrity of their work.

Funding: This research received no external funding.

Acknowledgments: The authors would like to acknowledge and thank the two peer reviewers for their thoughtful and valuable comments, which have undoubtedly helped improve the quality of this article.

Conflicts of Interest: The authors declare no conflict of interest.

\section{References}

Abdelrahim, Yasser Abuelmakarem A. 2019. Visual Analysis of ISIS Discourse Strategies and Types in Dabiq and Rumiyah Online Magazines. Visual Communication Quarterly 26: 63-78. [CrossRef]

Almond, Philip C. 1988. The British Discovery of Buddhism. Cambridge: Cambridge University Press.

Al-Rasheed, Madawi, and Marat Shterin, eds. 2009. Dying for Faith: Religiously Motivated Violence in the Contemporary World. London, New York and Melbourne: I.B. Tauris.

Aly, Anne, Stuart Macdonald, Lee Jarvis, and Thomas M. Chen. 2017. Introduction to the Special Issue: Terrorist Online Propaganda and Radicalization. Studies in Conflict \& Terrorism 40: 1-9.

Anonymous Interview: 2019. 2019, Adjumani, Uganda, January 14.

Appleby, Scott R. 2000. The Ambivalence of the Sacred: Religion, Violence, and Reconciliation. Lanham: Rowman and Littlefield.

Appleby, R. Scott, Atalia Omer, and David Little, eds. 2015. The Oxford Handbook of Religion, Conflict, and Peacebuilding. New York: Oxford University Press.

Bercovitch, Jacob, and Ayse Kadayifci-Orellana. 2009. Religion and Mediation: The Role of Faith-Based Actors in International Conflict Resolution. International Negotiation 14: 175-204. [CrossRef] 
Bhattarai, Prakash. 2016. Third-party coordination in conflict resolution: Evidence from Nepal and the Philippines. International Journal of Conflict Management 27: 398-423. [CrossRef]

Boesenecker, Aaron, and Leslie Vinjamuri. 2011. Lost in Translation? Civil Society, Faith-Based Organizations and the Negotiation of International Norms. International Journal of Transitional Justice 5: 345-65. [CrossRef]

Bruce, Steve. 2002. God Is Dead: Secularization in the West. Oxford: Blackwell.

Business for Peace. 2014. Business: A Powerful Force for Supporting Interfaith Understanding and Peace. New York: UN Global Compact.

Clarke, Gerard. 2008. Faith-based organizations and international development: An overview. In Development, Civil Society and Faith-Based Organizations: Bridging the Sacred and the Secular. Edited by Clarke Gerard and Michael Jennings. London: Palgrave MacMillan, pp. 17-45.

Conflict Sensitivity Consortium. 2012. How to Guide to Conflict Sensitivity. London: UKaid.

Coward, Harold, and Gordon S. Smith, eds. 2004. Religion and Peacebuilding. Albany: Albany State University Press.

Denscombe, Martyn. 2014. The Good Research Guide: For Small Scale Social Research Projects. Maidenhead: Open University Press.

Dwyer, Sonya Corbin, and Jennifer L. Buckle. 2009. The Space Between: On Being an Insider-Outsider in Qualitative Research. International Journal of Qualitative Methods 8: 54-63. [CrossRef]

Eller, Jack David. 2010. Cruel Creeds, Virtuous Violence: Religious Violence across Culture and History. Amherst: Prometheus Books.

Fjelde, Hanne, and Gudrun Østby. 2014. Socioeconomic Inequality and Communal Conflict: A Disaggregated Analysis of Sub-Saharan Africa, 1990-2008. International Interactions 40: 737-62. [CrossRef]

Fox, Jonathan. 2004. The Rise of Religious Nationalism and Conflict: Ethnic Conflict and Revolutionary Wars, 1945-2001. Journal of Peace Research 41: 715-31. [CrossRef]

Frazer, Owen, and Richard Friedli. 2015. Approaching Religion in Conflict Transformation: Concepts, Cases and Practical Implications. Zurich: CSS Mediation Resources.

Frazer, Owen, and Mark Owen. 2018. Religion in Conflict and Peacebuilding: Analysis Guide. Washington: United Sates Institute of Peace.

Gopin, Marc. 2000. Between Eden and Armageddon: The Future of World Religions, Violence, and Peacemaking. Oxford: Oxford University Press.

Haynes, Jeffrey. 2007. Religion and Development: Conflict or Cooperation? London: Palgrave Macmillan.

Herbert, Walter. 2009. Faith-Based War: From 9/11 to Catastrophic Success in Iraq. Sheffield: Equinox Publishing.

Hertog, Katrien. 2010. The Complex Reality of Religious Peacebuilding: Conceptual Contributions and Critical Analysis. Lanham: Lexington Books.

International Alert and Saferworld. 2004. Conflict-Sensitive Approaches to Development, Humanitarian Assistance and Peacebuilding. Available online: https:/www.international-alert.org/publications/conflict-sensitiveapproaches-development-humanitarian-assistance-and-peacebuilding (accessed on 7 March 2019).

Juergensmeyer, Mark. 2003. Terror in the Mind of God. Berkeley: University of California Press.

Juergensmeyer, Mark, and Margo Kitts, eds. 2011. Princeton Readings in Religion and Violence. Princeton: Princeton University Press.

Kolas, Ashild. 1996. Tibetan Nationalism: The Politics of Religion. Journal of Peace Research 33: 51-66. [CrossRef]

Lederach, John Paul. 1997. Building Peace: Sustainable Reconciliation in Divided Societies. Washington: United States Institute of Peace.

Leonardsson, Hanna, and Gustav Rudd. 2015. The 'local turn' in Peacebuilding: A Literature Review of Effective and Emancipatory Local Peacebuilding. Third World Quarterly 36: 825-39. [CrossRef]

Lundqvist, Martin Ola, and Joakim Öjendal. 2018. Atomised and Subordinated? Unpacking the Role of International Involvement in 'the Local Turn' of Peacebuilding in Nepal and Cambodia. Journal of Peacebuilding and Development 13: 16-30. [CrossRef]

Mac Ginty, Roger. 2012. Routine peace: Technocracy and peacebuilding. Cooperation and Conflict 47: $287-308$. [CrossRef]

McTernan, Oliver. 2003. Violence in God's Name: The Role of Religion in an Age of Conflict. London: Darton, Longman and Todd Ltd.

Morgan, George, and Scott Poynting, eds. 2016. Global Islamophobia: Muslims and Moral Panic in the West. Abingdon-on-Thames: Routledge. 
Mubashir, Mir, and Luxshi Vimalarajah. 2016. Tradition and Faith-Oriented Insider Mediators (TFIMs) as Crucial Actors in Conflict Transformation: Potential, Constraints, and Opportunities for Collaborative Support. Helsinki: The Network for Religious and Traditional Peacemakers.

Omer, Atalia. 2012. Religious Peacebuilding: The Exotic, the Good, and the Theatrical. Practical Matters 5: 1-31. Omer, Atalia. 2018. When 'good religion' is good. Journal of Religious and Political Practice 4: 122-36. [CrossRef] Powell, Jonathan. 2015. Talking to Terrorists: How to End Armed Conflicts. London: The Bodley Head.

Rudolph, Susanne. 2018. Transnational Religion and Fading States. New York: Routledge.

Sampson, Cynthia. 1997. Religion and Peacebuilding. In Peacemaking in International Conflict: Methods and Techniques. Edited by William Zartman. Washington: United States Institute of Peace Press, pp. 273-316.

Schwarz, Tanya B. 2018. Faith-Based Organizations in Transnational Peacebuilding. Lanham: Rowman and Littlefield International.

Schwarz, Tanya B., and Cecelia Lynch. 2016. Religion in International Relations. World Politics. [CrossRef]

Shannahan, Chris, and Laura Payne. 2016. Faith-Based Interventions in Peace, Conflict and Violence: A Scoping Study. Coventry: Centre for Trust, Peace and Social Relations and Joint Learning Initiative.

Shehabat, Ahmad, and Teodor Mitew. 2018. Black-boxing the Black Flag: Anonymous Sharing Platforms and ISIS Content Distribution Tactics. Perspectives on Terrorism 12: 81-99.

Sisk, Timothy D., ed. 2011. Between Terror and Tolerance: Religious Leaders, Conflict, and Peacemaking. Georgetown: Georgetown University Press.

Snodderly, Dan. 2018. Peace Terms: Glossary of Terms for Conflict Management and Peacebuilding. Washington: United Sates Institute of Peace.

Snyder, Jack, ed. 2011. Religion and International Relations Theory. New York: Columbia University Press.

Stern, Jessica. 2009. Terror in the Name of God. New York: HarperCollins.

Toft, Monica Duffy, Daniel Philpott, and Shah Timothy. 2011. God's Century: Resurgent Religion and Global Politics. New York: W.W. Norton and Co.

Wallensteen, Peter. 2012. Understanding Conflict Resolution. London: Sage.

Walton, Matthew J., and Susan Hayward. 2014. Contesting Buddhist Narratives: Democratization, Nationalism, and Communal Violence in Myanmar. Honolulu: East-West Center.

Yin, Robert. K. 1994. Case Study Research: Design and Methods, 2nd ed. Thousand Oaks: Sage.

Yin, Robert. K. 2012. Applications of Case Study Research. Thousand Oaks: Sage.

(C) 2019 by the authors. Licensee MDPI, Basel, Switzerland. This article is an open access article distributed under the terms and conditions of the Creative Commons Attribution (CC BY) license (http://creativecommons.org/licenses/by/4.0/). 